\title{
Effects of encapsulated niacin on metabolism and production of periparturient dairy cows
}

\author{
S. D. Morey, ${ }^{\star}$ L. K. Mamedova, ${ }^{\star}$ D. E. Anderson,† C. K. Armendariz, ${ }^{\star}$ E. C. Titgemeyer, ${ }^{\star}$ and B. J. Bradford ${ }^{\star 1}$ \\ ${ }^{*}$ Department of Animal Sciences and Industry, and \\ †Department of Clinical Sciences, Kansas State University, Manhattan 66506
}

\section{ABSTRACT}

Nicotinic acid (niacin) can suppress lipolysis, but responses to dietary niacin have been inconsistent in cattle. Our aim was to determine if $24 \mathrm{~g} / \mathrm{d}$ of encapsulated niacin (EN; providing $9.6 \mathrm{~g} / \mathrm{d}$ of bioavailable nicotinic acid) alters lipid metabolism and productivity of transition cows. Beginning $21 \mathrm{~d}$ before expected calving, primiparous $(\mathrm{n}=9)$ and multiparous $(\mathrm{n}=13)$ cows (body condition score of $3.63 \pm 0.08$ ) were sequentially assigned within parity to EN (12 g provided with ration twice daily) or control through $21 \mathrm{~d}$ postpartum. Liver biopsies were collected on $\mathrm{d}-21,-4,1,7$, and 21 relative to parturition. Blood samples were collected on $\mathrm{d}-21,-14,-7,-4,1,4,7,14$, and 21 relative to parturition. On d 7 postpartum, a caffeine clearance test was performed to assess liver function, and on d 21 to 23 postpartum, blood samples were collected every $8 \mathrm{~h}$ to monitor posttreatment nonesterified fatty acid (NEFA) responses. Data were analyzed using mixed models with repeated measures over time. A treatment $\times$ time $\times$ parity effect was observed on prepartum dry matter intake (DMI), which was caused by a $4 \mathrm{~kg} / \mathrm{d}$ decrease in DMI of EN-treated multiparous cows compared with control multiparous cows during the final 4 d prepartum. A significant increase in plasma nicotinamide concentration occurred in EN-treated cows on d -7 and 21 relative to parturition. Prepartum glucose concentration decreased in treated animals, with no difference in plasma insulin concentration. Treatment $\times$ time $\times$ parity effects were detected for NEFA and $\beta$-hydroxybutyrate concentrations during the postpartum period. Plasma NEFA peaked at 1,467 $\pm 160 \mu M$ for control animals compared with $835 \pm 154 \mu M$ for EN-treated animals. After treatments ended on d 21, no evidence was found for a plasma NEFA rebound in either parity group. A treatment $\times$ parity $\times$ time interaction was detected for liver triglyceride content, indicating a tendency for less liver triglyceride in EN-

Received February 24, 2011.

Accepted June 20, 2011.

${ }^{1}$ Corresponding author: bbradfor@ksu.edu treated primiparous cows, but caffeine clearance rates were not affected by treatment. No treatment effects were observed for body condition score, body weight, energy balance, or milk or milk component production. A high dose of EN can decrease postpartum plasma NEFA concentration, but may also decrease prepartum DMI.

Key words: niacin, transition, ketosis, periparturient

\section{INTRODUCTION}

Fatty liver affects up to $50 \%$ of postpartum dairy cattle, which is costly due to milk production losses and secondary diseases such as ketosis (Bobe et al., 2004). Fatty liver occurs when cattle enter a negative energy balance (NEB), usually during the first 2 wk of lactation (Grummer, 1993). Lipolysis occurs as a response to the NEB and results in the liver being overwhelmed by high concentrations of plasma NEFA (Ingvartsen and Andersen, 2000). The high influx of NEFA to the liver is usually greater than its oxidative capacity, resulting in storage of NEFA as triglyceride (TG) within the hepatocytes (Drackley et al., 2001).

Use of niacin (nicotinic acid; NA) in dairy cattle is widely studied; however, results have been inconclusive or contradictory. Niacin is a B vitamin that is required in very small amounts to maintain cellular metabolism (NRC, 2001). At much higher doses, NA also has the ability to suppress the release of fat stores (Pires et al., 2007). As a widely used commercial feed additive, NA is claimed to reduce heat stress (Di Costanzo et al., 1997) and decrease postpartum plasma NEFA concentrations (Pires and Grummer, 2007). Experimentally, NA has been shown to have antilipolytic effects, causing an immediate reduction in plasma NEFA when given postruminally (Pires and Grummer, 2007). Niacin binds to the G-protein coupled receptor GPR109A, causing inhibition of adenyl cyclase activity and a subsequent reduction of intracellular cyclic AMP (cAMP), leading to suppression of lipolysis (Wise et al., 2003). This receptor also has high affinity for BHBA, a ketone that is of considerable interest in postpartum dairy cows due to the high prevalence of ketosis. 
Supplemented NA has poor stability in the rumen and it is estimated that only $5 \%$ is bioavailable, making supplementation inefficient (Santschi et al., 2005). A rumen-protected form of NA (encapsulated niacin; EN) is commercially available, providing a more effective option for dietary supplementation of NA. This product (Niashure, Balchem Corp., New Hampton, $\mathrm{NY}$ ) is in the form of small pellets that include a core of NA surrounded by several layers of lipids. Because these lipids are relatively insoluble in the rumen, the majority of the pellets exit the rumen intact, largely preventing microbial degradation of the EN.

Until this experiment, no known studies have been conducted to explore the metabolic and production responses to EN in peripartum dairy cows. The purpose of this study was to determine if $24 \mathrm{~g} / \mathrm{d}$ of dietary EN could suppress lipolysis enough to control plasma NEFA in postpartum dairy cattle, potentially preventing or reducing the severity of fatty liver.

\section{MATERIALS AND METHODS}

All experimental procedures were approved by the Kansas State University Institutional Animal Care and Use Committee.

\section{Design and Treatments}

A total of 22 Holstein cows ( $\mathrm{n}=9$ primiparous and $\mathrm{n}=13$ multiparous) from the Kansas State University Dairy Teaching and Research Facility were randomly assigned within parity to receive either 0 or $24 \mathrm{~g} / \mathrm{d}$ of EN beginning $21 \mathrm{~d}$ before expected calving date and continuing until $21 \mathrm{~d}$ postpartum. This dose was based on a typical human dose of 1 to $4 \mathrm{~g} / \mathrm{d}$ (Carlson, 2006), which can be extrapolated to a dose of approximately 10 to $40 \mathrm{~g} / \mathrm{d}$ for an average Holstein cow. According to product literature, the EN product was estimated to provide $40 \%$ bioavailable NA, which would result in supplementation of $9.6 \mathrm{~g} / \mathrm{d}$. Cows entered the study from June 2008 to August 2008. Dry matter intake and milk production were measured daily until d 21 postpartum. Cattle were housed in a tie-stall facility in randomly assigned stalls, milked 3 times daily (0400, 1100 , and $2100 \mathrm{~h}$ ) and fed twice daily (0700 and 1500 h) at $110 \%$ of the previous day's intake. Prepartum and postpartum diets (Table 1) were formulated to meet requirements (NRC, 2001). All cows were fed similarly, except that treated cows received $12 \mathrm{~g}$ of EN at each feeding mixed by hand into the top $10 \%$ of the ration.

\section{Data and Sample Collection}

Feed ingredient and TMR samples were collected every 2 wk, and corn silage DM was determined twice weekly and adjusted in ration formulations. Milk yields were recorded at each milking, and milk was sampled at every milking beginning at 4 DIM until cows exited the study.

Liver biopsies were taken on $\mathrm{d}-21,-4,1,7$, and 21 relative to parturition. Blood was collected on $\mathrm{d}-21$, $-14,-7,-4,1,4,7,14$, and 21 . On each collection day, liver biopsies and blood samples were taken at $1300 \mathrm{~h}$. Approximately $14 \mathrm{~mL}$ of blood was collected from the coccygeal vein and immediately emptied into 2 tubes, one containing potassium EDTA and the other containing potassium oxalate with sodium fluoride as a glycolytic inhibitor (Vacutainer, Becton Dickinson, Franklin Lakes, NJ). Both were centrifuged at 2,000 $\times g$ for 15 min immediately after sample collection, and plasma was harvested and frozen at $-20^{\circ} \mathrm{C}$ until analysis. Liver samples were collected using a 14-gauge $\times 15 \mathrm{~cm}$ biopsy needle (SABD-1415-15-T, US Biopsy, Franklin, IN). Liver tissue was collected between the 10th and 11th ribs, $5 \mathrm{~cm}$ dorsal to a line between the olecranon and tuber coxae. The area was shaved, aseptically prepared, and anesthetized with $2 \mathrm{~mL}$ of subcutaneous lidocaine hydrochloride. Anesthesia was assessed by cutaneous response after 5 min, and a \#11 Bard Parker blade was used to make a stab incision into the body wall. The biopsy needle was inserted cranioventrally toward the liver and approximately $100 \mathrm{mg}$ of tissue was collected (total of 5 biopsies), snap-frozen in liquid $\mathrm{N}_{2}$, and stored at $-80^{\circ} \mathrm{C}$ until analysis. The BCS was determined by 3 trained investigators on $\mathrm{d}-21,-4,1,7$, and 21 on a 1 to 5 scale according to Wildman et al. (1982). Cow BW was measured on d 1, 7, 14, and 21 at $1300 \mathrm{~h}$.

On d 7 postpartum, a caffeine clearance test was performed to assess liver function, following the protocol of Lakritz et al. (2006). Jugular catheters (\#1411, Mila International, Erlanger, KY) were placed and caffeine was administered intravenously $(2 \mathrm{mg} / \mathrm{kg}$ of $\mathrm{BW})$ as caffeine and sodium benzoate (C4144, Sigma-Aldrich Co., St. Louis, MO) in a sterile pyrogen-free normal saline solution (50 $\mathrm{mg}$ of caffeine/mL of solution). Blood was collected into $\mathrm{K}_{3}$ EDTA-containing tubes (Vacutainer, Becton Dickinson) every 30 min for $180 \mathrm{~min}$ and centrifuged $(15 \mathrm{~min}$ at $2,000 \times \mathrm{g})$, and the plasma was removed and stored at $-20^{\circ} \mathrm{C}$ until analysis. Catheters were maintained by flushing with $6 \mathrm{~mL}$ of sterile $3.5 \%$ sodium citrate solution following each collection. On d 21 postpartum, jugular catheters were placed for 48 h. Blood was collected as above every $8 \mathrm{~h}$ to assess if a posttreatment increase (rebound) in plasma NEFA concentration occurred.

\section{Liver and Plasma Analyses}

Approximately $20 \mathrm{mg}$ of liver was placed into 500 $\mu \mathrm{L}$ of chilled PBS ( $\mathrm{pH}$ 7.4) and homogenized. The ho- 
Table 1. Composition and nutrient analysis of diets (\% of DM)

\begin{tabular}{|c|c|c|}
\hline Item & Prepartum & Postpartum \\
\hline \multicolumn{3}{|l|}{ Ingredient } \\
\hline Corn silage & 24.2 & 26.7 \\
\hline Prairie hay & 27.7 & - \\
\hline Alfalfa hay & - & 14.5 \\
\hline Wet corn gluten feed ${ }^{1}$ & 34.6 & 35.3 \\
\hline Ground corn & 10.0 & 14.5 \\
\hline Mechanically extracted soybean meal $^{2}$ & - & 6.4 \\
\hline Solvent-extracted soybean meal $(48 \% \mathrm{CP})$ & 3.24 & - \\
\hline Salt & 0.08 & - \\
\hline Vitamin A premix $(30 \mathrm{kIU} / \mathrm{g})$ & 0.01 & 0.02 \\
\hline Vitamin D premix (30 kIU/g) & 0.03 & $<0.01$ \\
\hline Vitamin E premix (44 IU/g) & 0.02 & 0.04 \\
\hline Selenium premix (600 mg/kg) & 0.03 & 0.04 \\
\hline Ethylenediamine dihydriodide premix $(3.65 \%$ I) & $<0.01$ & $<0.01$ \\
\hline Organic trace mineral supplement ${ }^{3}$ & 0.07 & 0.16 \\
\hline Limestone & - & 1.7 \\
\hline Trace mineral salt ${ }^{4}$ & - & 0.14 \\
\hline Sodium bicarbonate & - & 0.41 \\
\hline Organic trace mineral supplement ${ }^{5}$ & - & 0.06 \\
\hline Magnesium oxide & - & 0.08 \\
\hline \multicolumn{3}{|l|}{ Nutrient } \\
\hline DM (\% as-fed) & 63.8 & 60.9 \\
\hline $\mathrm{CP}$ & 13.8 & 18.9 \\
\hline NDF & 41.3 & 27.9 \\
\hline Starch & 17.9 & 22.7 \\
\hline $\mathrm{NFC}^{6}$ & 35.5 & 42.0 \\
\hline Ether extract & 2.4 & 2.9 \\
\hline Ash & 7.0 & 8.2 \\
\hline \multicolumn{3}{|l|}{${ }^{1}$ Sweet Bran (Cargill Inc., Blair, NE). } \\
\hline \multicolumn{3}{|l|}{${ }^{2}$ SoyBest (Grain States Soya, West Point, NE). } \\
\hline \multicolumn{3}{|c|}{$\begin{array}{l}{ }^{3} 4 \text {-Plex (Zinpro Corp., Eden Prairie, MN) consists of zinc } 2.58 \% \text {, manganese } 1.48 \% \text {, copper } 0.90 \% \text {, cobalt } \\
0.18 \% \text {, methionine } 8.21 \% \text {, and lysine } 3.80 \% \text {. }\end{array}$} \\
\hline \multicolumn{3}{|c|}{$\begin{array}{l}{ }^{4} \text { Provided sodium } 38 \% \text {, chloride } 59 \% \text {, cobalt } 0.005 \% \text {, copper } 0.03 \% \text {, iron } 0.2 \% \text {, iodine } 0.007 \% \text {, manganese } 0.2 \% \text {, } \\
\text { and zinc } 0.35 \% \text {. }\end{array}$} \\
\hline \multicolumn{3}{|c|}{$\begin{array}{l}{ }^{5} \text { MFP-Mintrex (Novus International, St. Charles, MO) consists of zinc } 2.26 \% \text {, copper } 1.06 \% \text {, manganese } 0.92 \% \text {, } \\
\text { biotin } 0.14 \% \text {, selenium } 0.026 \% \text {, and methionine } 22.2 \% \text {. }\end{array}$} \\
\hline
\end{tabular}

mogenate was centrifuged at $2,000 \times g$ for $10 \mathrm{~min}$ at $4^{\circ} \mathrm{C}$, and $100 \mu \mathrm{L}$ of the supernatant was then removed for free glycerol and total protein analysis. Triglyceride content was measured using a method adapted from Starke et al. (2010). The remaining liver homogenate was incubated with $100 \mu \mathrm{L}$ of lipase (porcine pancreatic lipase, MP Biomedicals, Solon, $\mathrm{OH}$ ) for $16 \mathrm{~h}$ at $37^{\circ} \mathrm{C}$, and glycerol content was then determined by an enzymatic glycerol phosphate oxidase method (\#F6428, Sigma-Aldrich Co.). Triglyceride content was calculated based on the difference between glycerol concentrations before and after lipase digestion. Total protein content of the original homogenate was analyzed by a Coomassie blue (Bradford, 1976) colorimetric method (kit \#23236, Thermo Scientific, Pierce, Rockford, IL). To avoid potential bias introduced by differences in moisture content of liver samples, liver TG concentration was normalized by protein concentration, which is unaltered in fatty liver (Fronk et al., 1980).

The mRNA abundance of GPR109A in liver tissue was determined by real-time PCR as described by
Bradford et al. (2009b). Briefly, RNA was extracted from tissue homogenate using the RNeasy Lipid Tissue Mini Kit (Qiagen Inc., Valencia, CA). Complementary DNA was then synthesized from $2 \mu \mathrm{g}$ of total RNA using the High Capacity cDNA Reverse Transcription kit (Applied Biosystems, Foster City, CA). Quantitative real-time PCR was performed in triplicate with $1 / 20$ of the cDNA product in the presence of 200 $\mathrm{nmol} / \mathrm{L}$ gene-specific forward and reverse primers with real-time SYBR green fluorescent detection (7500 Fast Real-Time PCR System, Applied Biosystems). Abundance of $\beta$-actin mRNA was also determined, and GPR109A abundance was expressed relative to this internal control gene. Primers for $\beta$-actin were designed from sequence NM_173979.3 (National Center for Biotechnology Information); forward = ACGACATGGAGAAGATCTGG, reverse = ATCTGGGTCATCTTCTCACG. Primers for GPR109A were designed from sequence \#XR_028237.1; forward = ACATCACCCTCAGCTTCACC, reverse = GCGGTTGTTATCCGACTCAT. The cycles to threshold 
values for $\beta$-actin were not affected by time $(P=0.39)$, treatment $(P=0.45)$, or their interaction $(P=0.53)$, validating its use as a control gene.

Plasma was analyzed for NEFA using an enzymatic colorimetric procedure (NEFA-HR, Wako Chemicals USA, Richmond, VA), glucose by a colorimetric kit (Autokit Glucose; Wako Chemicals USA), insulin by a bovine-specific sandwich ELISA (\#10-1201-01, Mercodia AB, Uppsala, Sweden), haptoglobin by a bovinespecific ELISA (kit \# 2410-7, Life Diagnostics, West Chester, PA), and BHBA using an enzymatic reaction (kit \#H7587-58, Pointe Scientific Inc., Canton, MI).

Plasma concentrations of NA and nicotinamide (NAM) were determined by HPLC with a method adapted from Lahély et al. (1999). Plasma samples (400 $\mu \mathrm{L}$ ) were acidified with $200 \mu \mathrm{L}$ of $1.5 \mathrm{M}$ perchloric acid, mixed, and centrifuged at $10,000 \times g$ for $10 \mathrm{~min}$. The supernatant $(400 \mu \mathrm{L})$ was recovered and $200 \mu \mathrm{L}$ of $1 M$ $\mathrm{K}_{2} \mathrm{CO}_{3}$ was added. The samples were mixed and then centrifuged at $10,000 \times g$ for $10 \mathrm{~min}$, and the resulting supernatant was collected for injection. A Discovery BIO Wide Pore C18 column $(25 \mathrm{~cm} \times 4.6 \mathrm{~mm}, 5 \mu \mathrm{m}$ particle size; Supelco \# 568223-U, Sigma-Aldrich) and Discovery BIO Wide Pore C18 guard column $(2 \mathrm{~cm} \times$ $4 \mathrm{~mm}, 5 \mu \mathrm{m}$ particle size; Supelco \#568272-U, SigmaAldrich) were used for all analyses. The photochemical reaction was carried out in a mobile phase consisting of $0.07 M \mathrm{KH}_{2} \mathrm{PO}_{4}, 0.075 M \mathrm{H}_{2} \mathrm{O}_{2}$, and $5.1 \mu M \mathrm{CuSO}_{4}$ at a $\mathrm{pH}$ of 4.25 in a polytetrafluoroethylene tube $(10 \mathrm{~m} \times$ $0.5 \mathrm{~mm}$ ) wound around a black light (300 to $400 \mathrm{~nm}$ ). Detection was carried out with a scanning fluorescence detector (HP 1046A, Hewlett-Packard) that operated at excitation and emission wavelengths of $322 \mathrm{~nm}$ and $380 \mathrm{~nm}$, respectively. The injection volume was $20 \mu \mathrm{L}$ and the flow rate was $0.8 \mathrm{~mL} / \mathrm{min}$.

Caffeine was analyzed using HPLC as described by Lakritz et al. (2006). Briefly, $250 \mu \mathrm{L}$ of plasma was added to $250 \mu \mathrm{L}$ of $0.8 \mathrm{M}$ perchloric acid and centrifuged at $14,000 \times g$ for $20 \mathrm{~min}$ at $21^{\circ} \mathrm{C}$. A $200-\mu \mathrm{L}$ aliquot of clarified supernatant was transferred into an autosampler vial containing $10 \mu \mathrm{L}$ of $4 \mathrm{M} \mathrm{NaOH}$. Vials were capped and $20 \mu \mathrm{L}$ was injected. The column and guard column were the same as described above, and the mobile phase was $20 \mathrm{~m} M$ phosphate buffer ( $\mathrm{pH}$ 3.0)-acetonitrile, 85:15 ( $\mathrm{vol} / \mathrm{vol}$ ), at a flow rate of $1 \mathrm{~mL} / \mathrm{min}$. Absorbance was read at $273 \mathrm{~nm}$ using an Acutect $500 \mathrm{UV} / \mathrm{Vis}$ detector (\#06-653-5, Thermo Fisher Scientific).

\section{Feed and Milk Analyses}

Diet ingredients and TMR samples were dried in a $55^{\circ} \mathrm{C}$ forced-air oven for $72 \mathrm{~h}$. Feed ingredients were analyzed for DM concentration, ground to pass through a 1-mm screen using a Wiley mill (Arthur H. Thomas, Philadelphia, PA) and composited by feed type on an equal mass basis. Ash concentration was determined after $5 \mathrm{~h}$ of oxidation at $500^{\circ} \mathrm{C}$ in a muffle furnace. Concentration of NDF was determined (Van Soest et al., 1991) using an Ankom Fiber Analyzer (Ankom Technology, Fairport, NY) including amylase and sodium sulfite. Crude protein was determined by oxidation and detection of $\mathrm{N}_{2}$ (Leco Analyzer, Leco Corp., St. Joseph, MI). Crude fat was determined by ether extraction (AOAC, 2000; method 920.9). Starch was determined by $\alpha$-amylase and glucoamylase digestion, followed by colorimetric glucose quantification using a commercial kit (Autokit Glucose; Wako Chemicals USA). Concentrations of all nutrients except for DM were expressed as percentages of $\mathrm{DM}$ determined by drying at $105^{\circ} \mathrm{C}$ in a forced-air oven for $16 \mathrm{~h}$. All analyses were performed in duplicate. Composition and nutrient analyses of prepartum and postpartum diets are shown in Table 1.

Milk samples were analyzed by Heart of America DHIA (Manhattan, KS) to determine concentrations of fat, true protein, lactose (B-2000 Infrared Analyzer; Bentley Instruments, Chaska, MN), urea nitrogen (MUN spectrophotometer, Bentley Instruments), and somatic cells (SCC 500, Bentley Instruments). Energycorrected milk $(0.327 \times$ milk yield $+12.86 \times$ fat yield $+7.65 \times$ protein yield; DHI glossary, Dairy Record Management Systems, 2009) and SCM yield (Tyrrell and Reid, 1965) were calculated.

\section{Disease Incidence}

Cows were assessed daily for health by rectal thermometer, stethoscope, and physical examination. Diseases recorded included displaced abomasum, ketosis, metritis, lameness, and "other digestive disorder" (diarrhea or hypermotile rumen). Ketosis was defined as having a plasma BHBA concentration $>1,400 \mu M$ at any point during the experimental period. This cut-off value was adapted from Duffield (2000) as a threshold for subclinical ketosis. Mastitis was defined as having a daily mean SCC $>400,000$ cells $/ \mathrm{mL}$. Other diseases were diagnosed according to definitions established by Kelton et al. (1998).

\section{Data and Statistical Analyses}

Data were analyzed using mixed models with repeated measures over time (SAS 9.1, SAS Inst. Inc., Cary, NC). Spatial power covariance structures were used to model repeated measures over time within cow. Fixed effects were treatment, parity, day, treatment $x$ parity, treatment $\times$ day, and treatment $\times$ parity $\times$ day. Cow was treated as a random effect. Plasma insulin 
and haptoglobin data also included $\mathrm{d}-21$ values as a covariate because of group differences before treatment initiation. Outliers were removed when studentized residuals were $>|3.0|$. Liver GPR109A mRNA, plasma haptoglobin, NA, and NAM data were log-transformed before analysis to achieve normal residual distributions, and reported means are back-transformed. Prepartum and postpartum measures were analyzed separately for DMI as well as plasma glucose, insulin, NEFA, and BHBA concentrations because of relatively discontinuous data at calving and an adequate number of data points pre- and postpartum. Treatment and 2-way interactions were declared significant at $P<0.05$, and trends are discussed at $P<0.10$. Three-way interactions were investigated at $P<0.10$.

Caffeine elimination half-lives were determined by plotting postinfusion concentrations over time for each animal, performing an exponential regression on these values $\left(y=a \times e^{-b x}\right.$, where $a=$ intercept and $b=$ slope), and using the equation half-life $=\ln 2 /$ slope (Lakritz et al., 2006). Slope and intercept values were used for subsequent analysis only if the regression $\mathrm{r}^{2}$ value was $>0.8$, which resulted in 18 values being used. Distribution volume was determined as the dose of caffeine infused divided by the intercept. Half-life and distribution volume data were analyzed using fixed effects of treatment, parity, and their interaction, and the random effect of cow. Disease incidence was analyzed using Fishers exact test, including 2 additional categories: having at least 1 disorder and having at least 2 disorders. Daily energy balance (d $5-21$ postpartum) was determined by the equation $\mathrm{NE}_{\mathrm{L}}$ intake - milk energy - maintenance energy (all in $\mathrm{Mcal} / \mathrm{d}$ ). Maintenance energy was calculated by the equation $\mathrm{BW}^{0.75}$ $\times 0.08$ (NRC, 2001); milk energy by the equation 0.75 $\times$ ECM (Tyrrell and Reid, 1965), and $\mathrm{NE}_{\mathrm{L}}$ density of the diet was estimated as $1.63 \mathrm{Mcal} / \mathrm{kg}$ of DM (NRC, 2001).

\section{RESULTS}

\section{DMI and Energy Balance}

Multiparous cows had higher DMI than primiparous cows $(P<0.01)$ and a time effect $(P<0.01)$ was observed, with all groups experiencing an increase in DMI from $\mathrm{d} 1$ to 21 (Figure 1 ). A treatment $\times$ parity $\times$ time interaction $(P<0.07)$ also occurred during the prepartum period, reflecting the decreased DMI of EN-treated multiparous cows compared with control multiparous cows $(P<0.02)$ by $4.1 \mathrm{~kg} / \mathrm{d}$ during the final $4 \mathrm{~d}$ before calving. Treatment did not affect postpartum DMI. A time effect was observed for energy balance $(P<0.01)$, but no significant differences were found between treatment or parity groups (Table 2).

\section{BW, BCS, and Milk Production}

Body condition (Table 2) and BW (data not shown) were not affected by treatment $(P>0.20)$; on average, animals lost 1 BCS unit (from 3.63 on d -21 to 2.62 on d $21 \pm 0.08)$ during the experiment. Milk production and components are shown in Table 2. As expected, multiparous cows produced higher yields of milk $(P<$ $0.01)$, fat $(P<0.01)$, protein $(P<0.001)$, and lactose $(P<0.01)$ than primiparous cows. Treatment did not affect milk production or milk components.

\section{Liver Tissue}

Liver TG content throughout the experiment is shown in Figure 2; no overall treatment or parity differences were found. All cows experienced an increase in liver TG following parturition $(P<0.001)$. A treatment $\times$ parity $\times$ time effect $(P<0.03)$ was observed due to a tendency $(P=0.10)$ for treated primiparous cows to have less triglyceride compared with control primiparous cows on $\mathrm{d} 1$ and 7 postpartum, but not on d 21 postpartum. Abundance of GPR109A mRNA in liver (data not shown) was not affected by treatment, parity, or time effects (all $P>0.20$; mean abundance relative to $\beta$-actin $=0.0028 \pm 0.0018)$.

\section{Plasma Parameters}

Plasma concentrations of BHBA and NEFA are displayed in Figure 3. A parity effect prepartum $(P<$ 0.02 ) was found due to primiparous cows having greater NEFA concentrations than multiparous cows. During the postpartum period, a treatment $\times$ time $\times$ parity interaction $(P<0.09)$ for plasma NEFA was detected, largely because peak elevations in plasma NEFA concentrations occurred later in control multiparous cows than in control primiparous cows, whereas cows receiving EN did not demonstrate large peaks postpartum. To better assess the ability of EN to suppress peak lipolysis postpartum, we quantified treatment effects on peak plasma NEFA concentrations measured for each cow. Plasma NEFA concentrations peaked at 1,467 \pm $160 \mu \mathrm{Eq} / \mathrm{L}$ for control cows compared with $835 \pm 154$ $\mu \mathrm{Eq} / \mathrm{L}$ for EN-treated cows $(P<0.01)$.

A treatment $\times$ time $\times$ parity interaction $(P<0.03)$ was observed for plasma BHBA concentration during the postpartum period. Although treatment did not significantly alter peak postpartum BHBA, EN-treated primiparous cows had lower BHBA concentrations than primiparous controls on d 7 postpartum (937 vs. 1,793 $\pm 261 \mu M ; P<0.02)$.

Concentrations of glucose and insulin are shown in Figure 4. Treatment did not affect plasma glucose 
Table 2. Milk production and composition, intake, and energy balance responses to encapsulated niacin (EN) during the periparturient period ${ }^{1}$

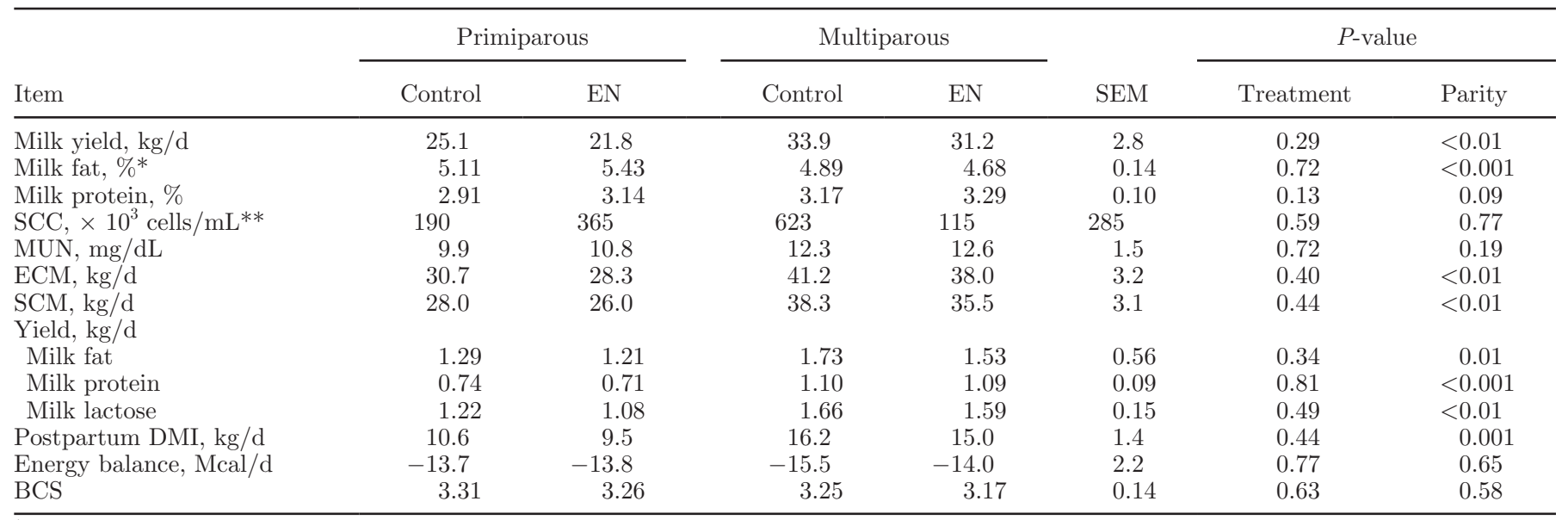

${ }^{1} \mathrm{EN}$ animals received $24 \mathrm{~g} / \mathrm{d}$ of dietary encapsulated niacin.

*Treatment $\times$ parity trend $(P=0.06) ; * *$ treatment $\times$ parity $\times$ DIM interaction $(P=0.06)$.

postpartum; however, EN treatment resulted in lower prepartum plasma glucose concentration $(P<0.04)$ compared with control. Both a parity effect prepartum $(P<0.01)$ and a trend postpartum $(P<0.07)$ were found for multiparous cows to have lower glucose than primiparous cows, and a significant time effect postpartum $(P<0.001)$ reflected the decrease in blood glucose after $\mathrm{d} 1$. A treatment $\times$ parity $\times$ time interaction $(P<$ $0.001)$ was detected for plasma insulin prepartum. On $\mathrm{d}-7$ relative to calving, EN-treated multiparous cows had greater plasma insulin concentrations than control multiparous cows $(P<0.02)$, and on $\mathrm{d}-4$ relative to calving, EN-treated primiparous cows had higher plasma insulin concentrations than control primiparous cows $(P<0.02)$. A time effect $(P<0.001)$ was also observed for plasma insulin caused by a decreasing concentration during the prepartum period.

Plasma NA (Figure 5) was unaffected by treatment, but primiparous cows had higher plasma NA than multiparous cows $(P<0.02)$, and NA increased for

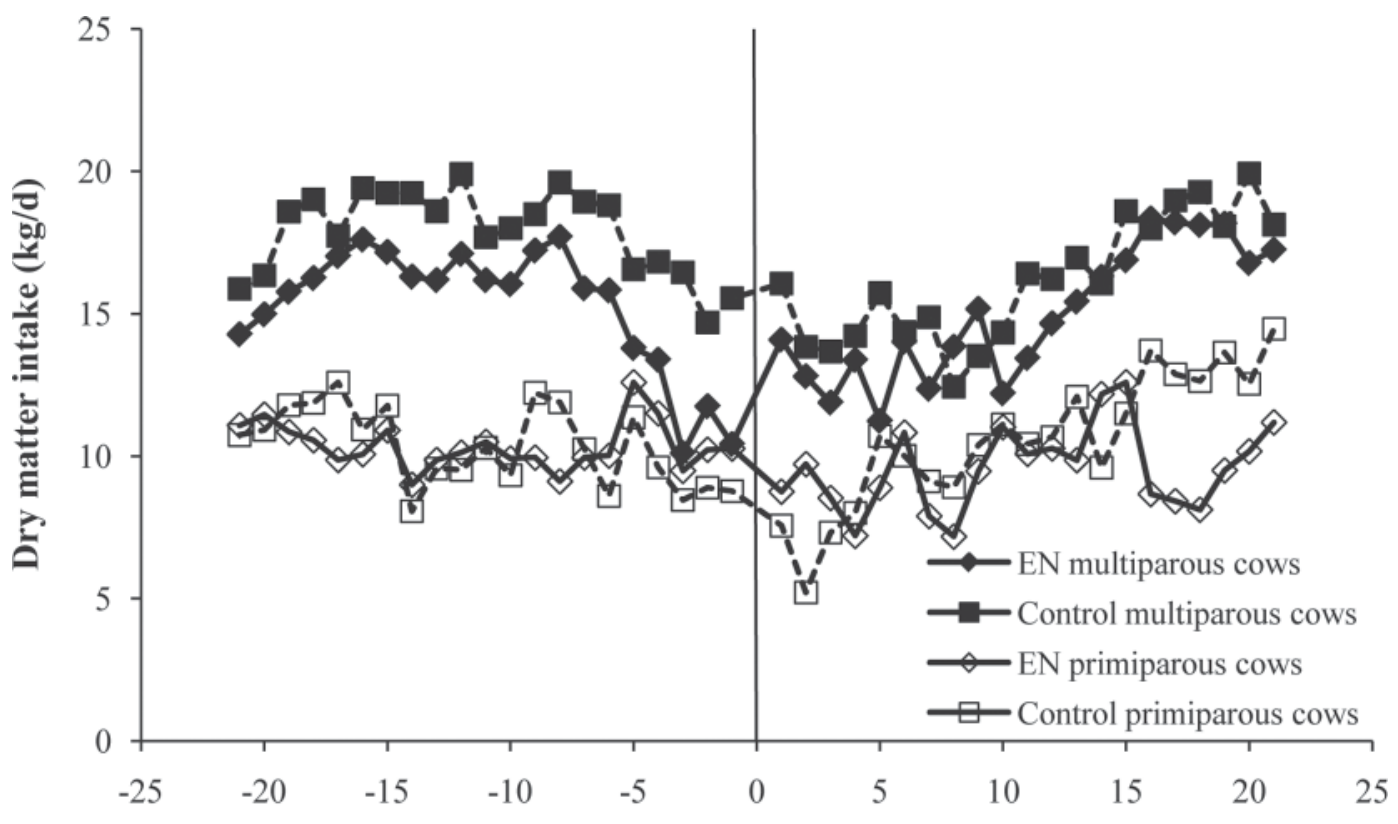

Day relative to expected calving

Figure 1. Dry matter intake responses to encapsulated niacin (EN) during the periparturient period. Multiparous cows had higher DMI than primiparous cows $(P<0.01)$. A treatment $\times$ parity $\times$ time interaction $(P<0.07)$ was caused by a decreased DMI for EN-treated multiparous cows by $4.1 \mathrm{~kg} / \mathrm{d}$ during the final $4 \mathrm{~d}$ prepartum $(P<0.02)$. Prepartum $\mathrm{SEM}=1.44 \mathrm{~kg} / \mathrm{d}$; postpartum SEM $=1.95 \mathrm{~kg} / \mathrm{d}, \mathrm{n}=4 \mathrm{to} 7$. The EN animals received $24 \mathrm{~g} / \mathrm{d}$ of dietary encapsulated niacin. 


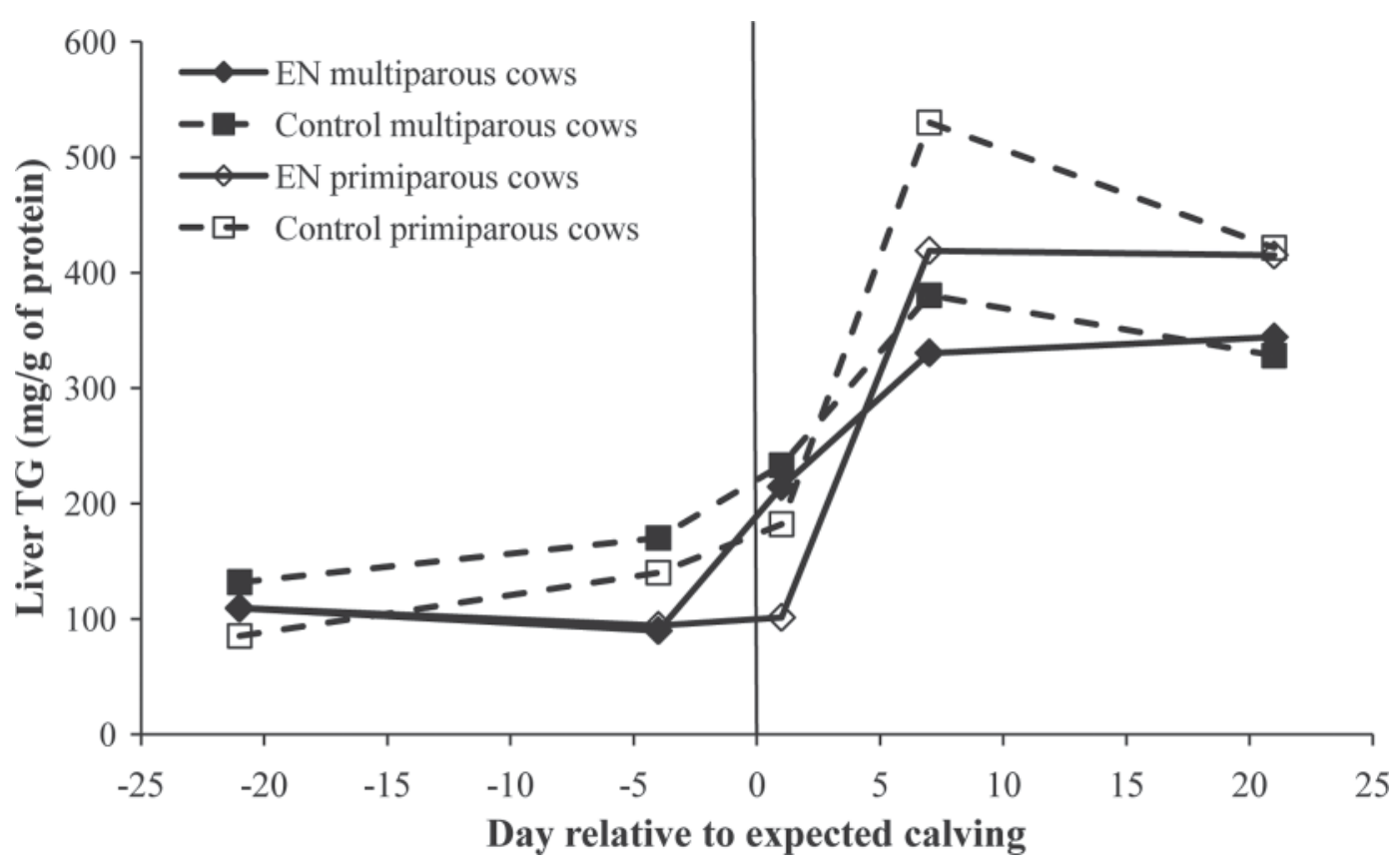

Figure 2. Liver triglyceride (TG) concentrations responses to encapsulated niacin (EN) during the periparturient period. No significant differences were found between treatment or parity groups, but a time effect $(P<0.001)$ was observed. A treatment $\times$ parity $\times$ time effect $(P<$ $0.03)$ exists due to a tendency $(P=0.10)$ for EN-treated primiparous cows to have less triglyceride than controls during d 1 and 7 . SEM $=48.5$ $\mathrm{mg} / \mathrm{g}, \mathrm{n}=4$ to 7 . The EN animals received $24 \mathrm{~g} / \mathrm{d}$ of dietary encapsulated niacin.

all animals over the course of the study $(P<0.001)$, most obviously after calving. Treatment with EN significantly increased plasma NAM $(P<0.001)$, and when individual days were tested, EN-treated cows had higher NAM on $\mathrm{d}-7$ and 21 relative to parturition ( $P$ $<0.001)$. Plasma NAM tended to remain elevated for EN cows on d $23(P<0.07), 50 \mathrm{~h}$ after the final EN treatment.

Plasma NEFA concentrations were measured every 8 $\mathrm{h}$ for $50 \mathrm{~h}$ following the first feeding without EN added. The treated group received EN at the morning feeding, and blood was first drawn at $1400 \mathrm{~h}$ that day, which was just before the next feeding. Results for posttreatment NEFA concentrations are shown in Figure 6. A time effect $(P<0.01)$ was found but no treatment or parity effects.

\section{Liver Indices and Disease Incidence}

Results of the caffeine challenge test are shown in Table 3. Treatment had no effect on caffeine clearance rate or volume of distribution $(P>0.90)$. The volume of distribution of caffeine was well correlated with $\mathrm{d} 7$ BW ( $\mathrm{r}=0.76 ; P<0.001)$, and multiparous cows had higher distribution volumes than did primiparous cows $(P<0.01)$, which was expected due to their larger BW.

For haptoglobin (Figure 7), treatment effects were not significant on any day, although a treatment $\times$ time trend $(P<0.06)$ was observed. However, a parity effect
$(P<0.03)$ was detected, with primiparous cows having higher haptoglobin concentrations than multiparous cows $(92.0$ vs. $42.0 \pm 9.6 \mu \mathrm{g} / \mathrm{mL})$. A time effect $(P<$ 0.001 ) was also detected for haptoglobin as a result of an increase in the early postpartum period. Although the overall incidence of disease was high in this study, no differences were found between treatment or parity groups (Table 4).

\section{DISCUSSION}

Cows in this study, across treatments, were relatively slow to increase DMI after parturition and had high rates of transition disorders compared with norms on commercial dairy farms. However, our data are not inconsistent with those from other studies in which cows were housed in tie-stalls with relatively intensive biological sampling protocols (Grummer et al., 2004; Dann et al., 2006). Results of this study may be most applicable to scenarios in which farms are experiencing unusually high incidence rates of metabolic disorders.

Fatty liver affects up to $50 \%$ of postpartum dairy cattle, occurring during the first 2 wk of lactation when cattle enter an NEB (Grummer, 1993). As a response to the NEB, fat stores are released and the liver is overwhelmed by high concentrations of plasma NEFA (Ingvartsen and Andersen, 2000). Previous work with supplemental NA has been inconclusive or contradictory. Although NA is only required in small amounts 

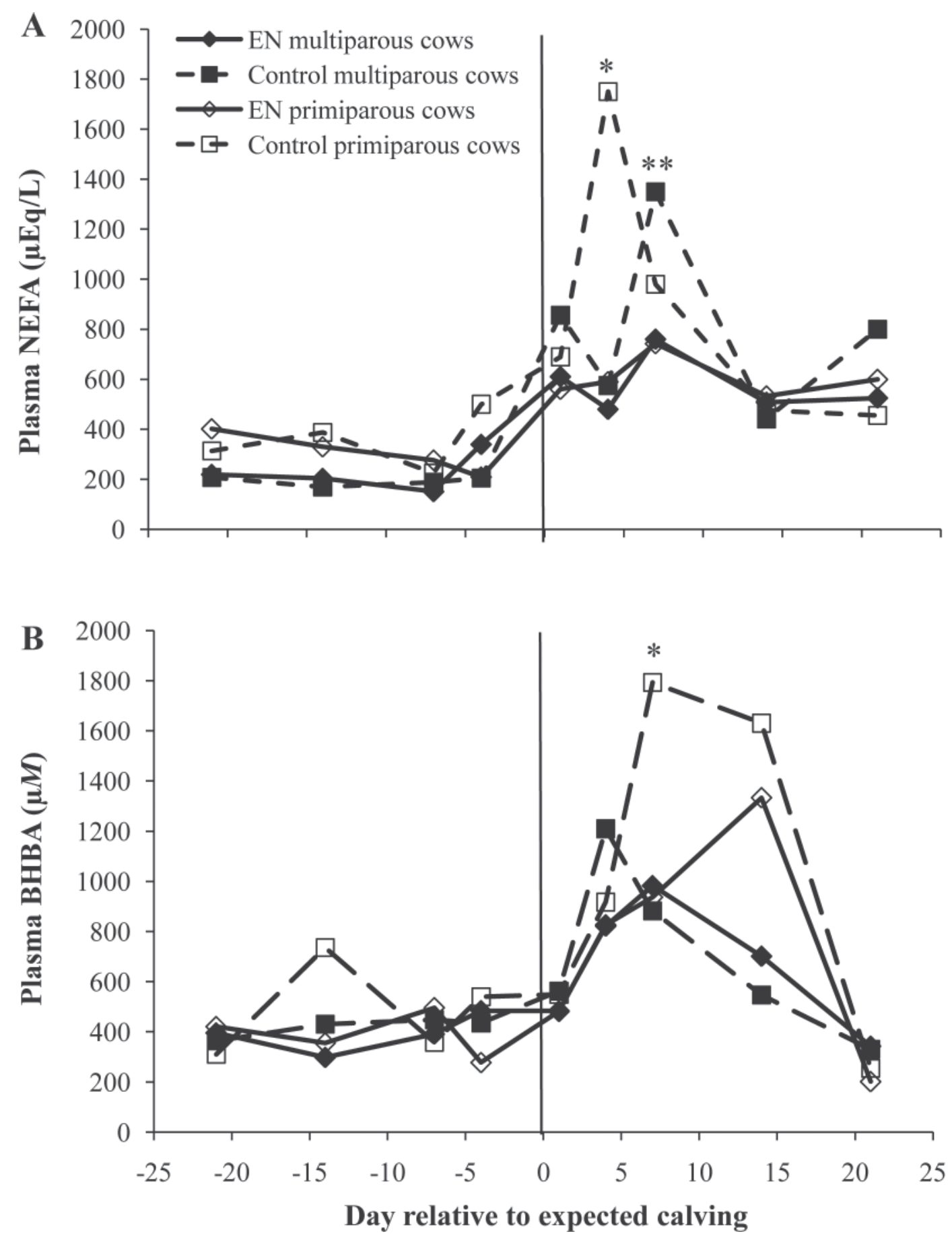

Figure 3. Plasma concentrations of NEFA (A) and BHBA (B) in response to encapsulated niacin (EN) during the periparturient period. (A) A treatment $\times$ time $\times$ parity interaction was detected $(P=0.09)$ after calving. Prepartum SEM $=82 \mu E q / L ; p o s t p a r t u m ~ S E M=216 \mu E q / L$, $\mathrm{n}=4$ to 7 . (B) A treatment $\times$ time $\times$ parity interaction was detected $(P<0.02)$ after calving. Prepartum SEM $=97 \mu M$; postpartum SEM $=234 \mu M, \mathrm{n}=4$ to $7 .{ }^{*}$ Indicates a treatment effect for primiparous cows $(P<0.05)$. ${ }^{* *}$ Indicates a treatment effect for multiparous cows $(P<$ 0.06). The EN animals received $24 \mathrm{~g} / \mathrm{d}$ of dietary encapsulated niacin.

to meet metabolic needs (NRC, 2001), pharmacological doses of NA have the ability to inhibit lipolysis (Pires et al., 2007).

As expected, both groups began the study with similar NAM concentrations. The increase in NA and NAM following parturition may have been from increased dietary niacin in the postpartum diet or increased production by ruminal microbes as intake of fermentable organic matter increased. Plasma NAM concentrations were about 100 times higher than NA concentrations 

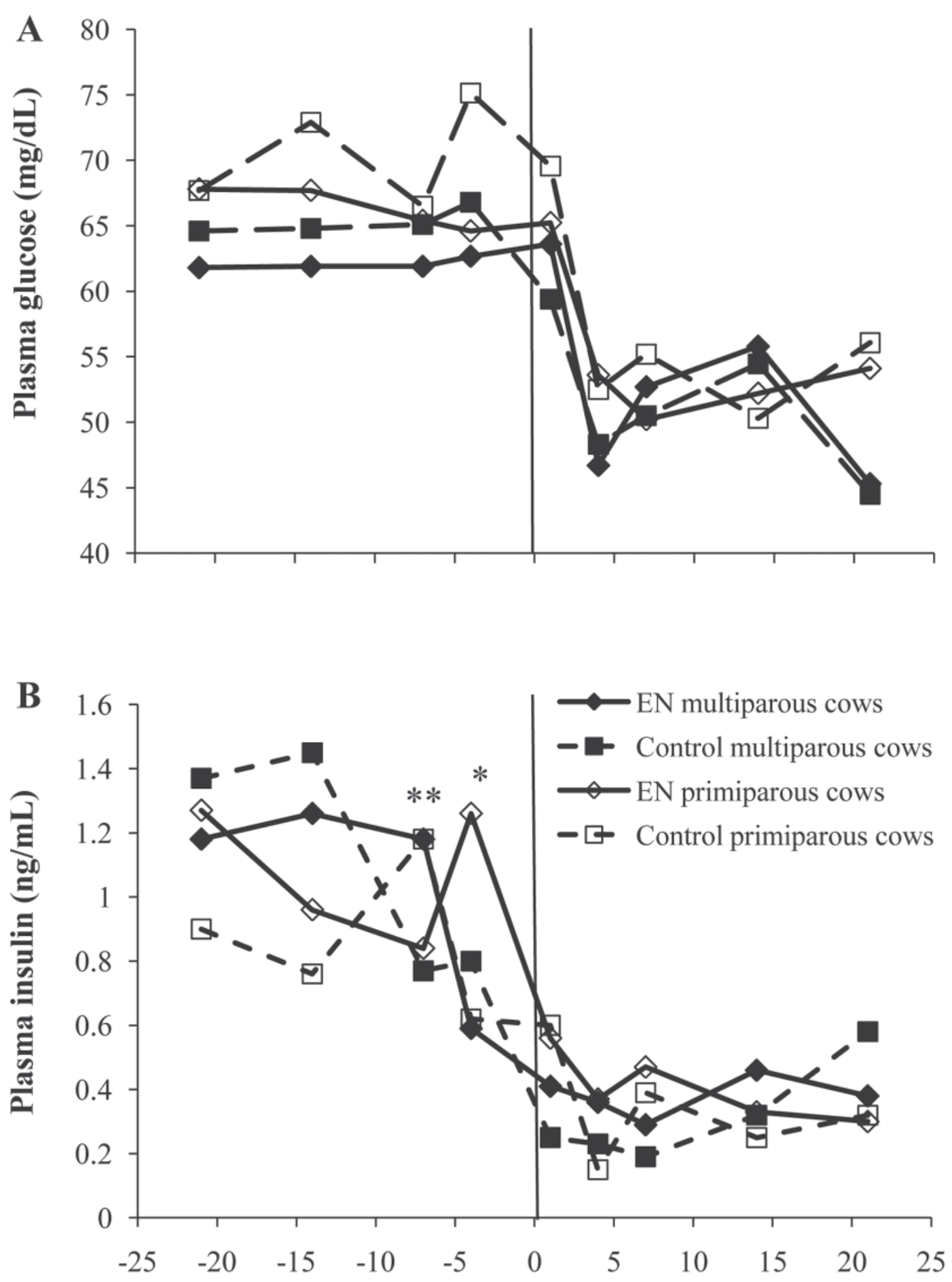

Day relative to expected calving

Figure 4. Plasma concentrations of glucose (A) and insulin (B) in response to encapsulated niacin (EN) during the periparturient period. (A) Treatment $(P<0.04)$ and parity $(P<0.01)$ effects were observed prepartum, and a time effect $(P<0.001)$ and a parity trend were observed postpartum $(P<0.07)$. Prepartum $\mathrm{SEM}=3.73 \mathrm{mg} / \mathrm{dL}$; postpartum $\mathrm{SEM}=2.70 \mathrm{mg} / \mathrm{dL}, \mathrm{n}=4$ to 7 . $(B)$ A treatment $\times$ parity $\times$ time effect was detected $(P<0.001)$ along with a time effect $(P<0.001)$. SEM $=0.61 \mathrm{ng} / \mathrm{mL}, \mathrm{n}=4$ to 7 . ${ }^{*}$ Indicates a treatment effect for primiparous cows. ${ }^{* *}$ Indicates a treatment effect for multiparous cows. The EN animals received $24 \mathrm{~g} / \mathrm{d}$ of dietary encapsulated niacin. 
A

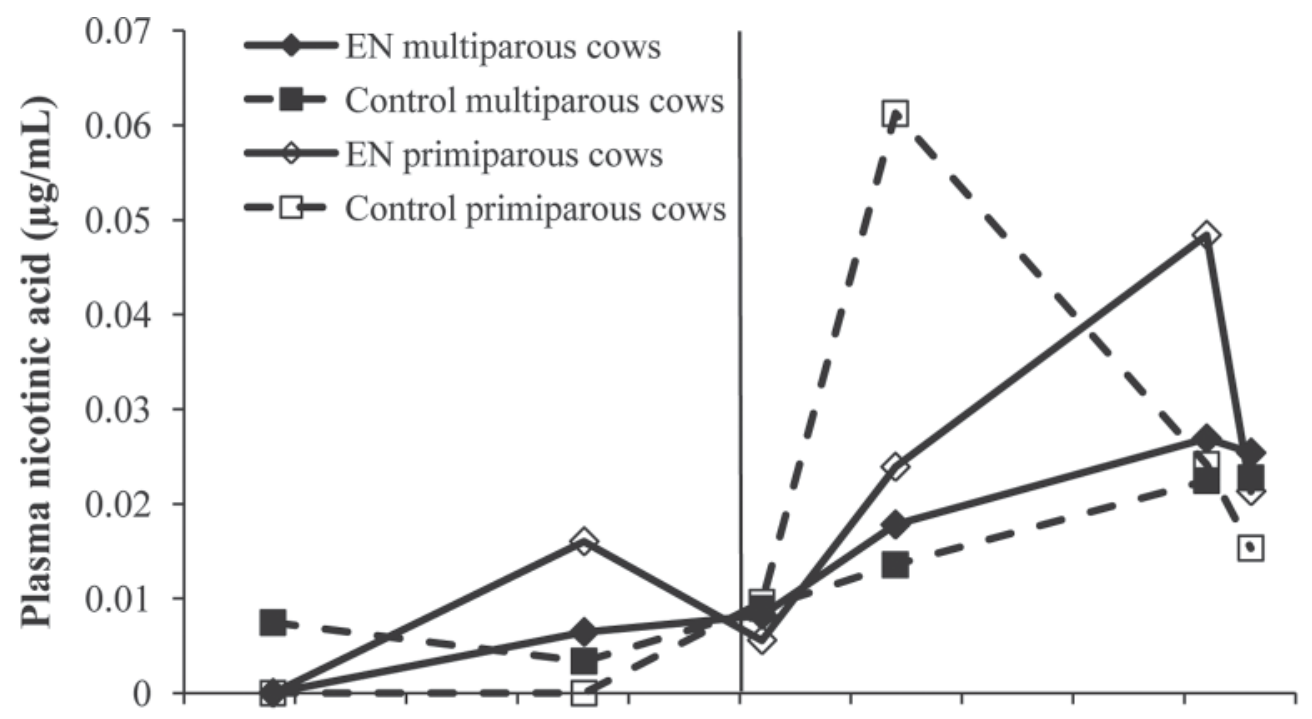

B

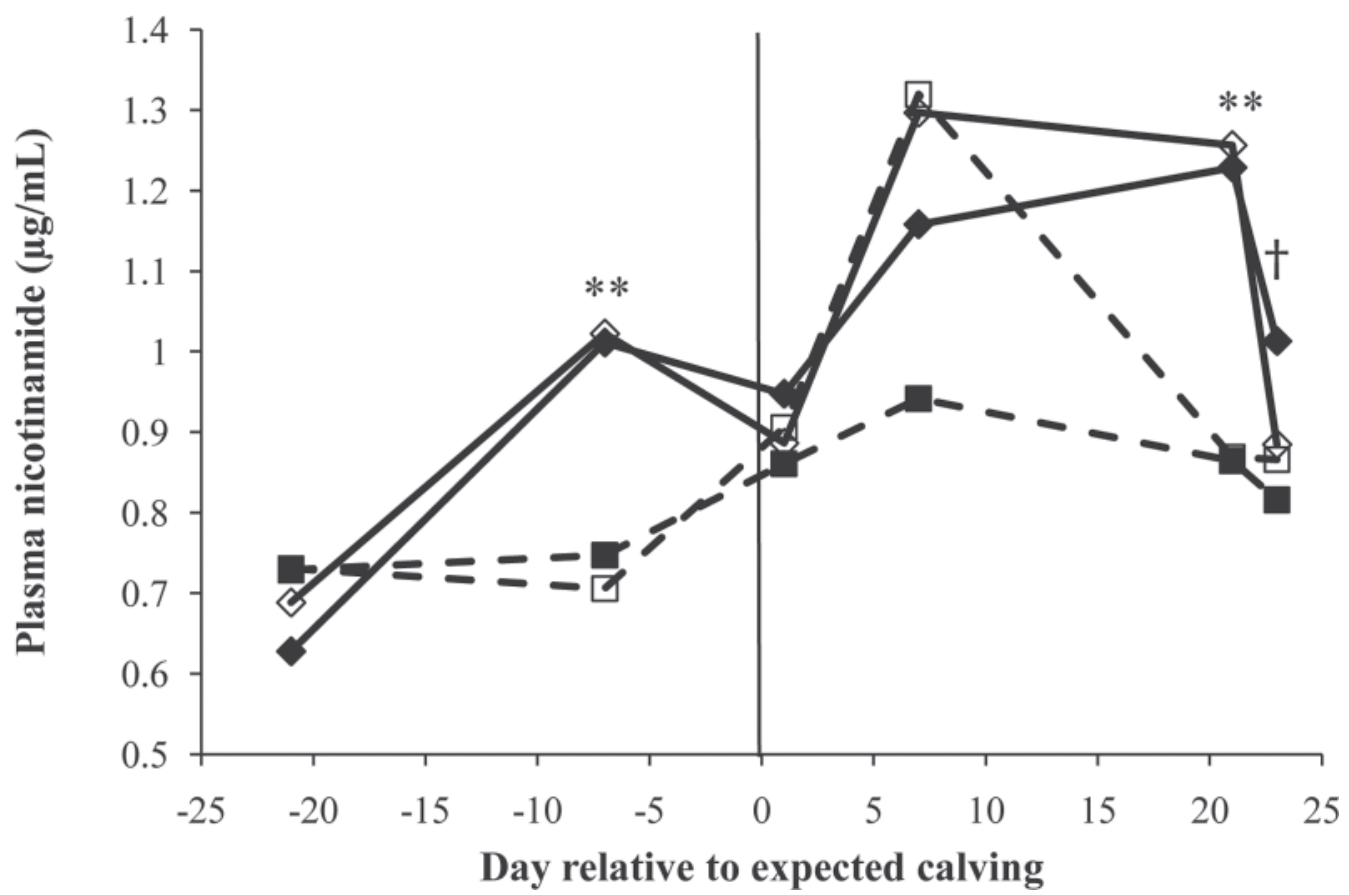

Figure 5. Plasma concentrations of (A) nicotinic acid and (B) nicotinamide in response to encapsulated niacin (EN) during the periparturient period. (A) Nicotinic acid was unaffected by treatment, but a parity effect $(P<0.02)$ was found from primiparous cows having higher nicotinic acid concentrations than multiparous cows and a time effect $(P<0.001)$ was found. SEM $=0.01 \mu \mathrm{g} / \mathrm{mL}, \mathrm{n}=4$ to 7 . (B) Treatment with EN raised plasma nicotinamide $(P<0.001)$ compared with control. This was caused by significant $(P<0.001)$ differences on $\mathrm{d}-7$ and 21. **Indicates significant $(P<0.001)$ differences between treatments; †indicates tendency for a treatment effect $(P<0.07)$. SEM $=0.093 \mu \mathrm{g} /$ $\mathrm{mL}, \mathrm{n}=4$ to 7 . The EN animals received $24 \mathrm{~g} / \mathrm{d}$ of dietary encapsulated niacin through $\mathrm{d} 21$ postpartum; the last time point is $50 \mathrm{~h}$ following treatment removal.

throughout the experiment. Several authors have reported that the acidic environment in the abomasum favors NA (Campbell et al., 1994; Santschi et al., 2005). However, most NA is absorbed from the duodenum and is rapidly converted to NAD and then hydrolyzed to NAM, which is the main transport form of niacin in the blood (Henderson, 1983). Therefore, we would expect that most of the NA we supplemented should have been converted to NAM after absorption. The difference in NA and NAM concentrations in this study can also be explained by the affinity for the GPR109A receptor. Nicotinic acid has a very high affinity for the GPR109A 
Table 3. Effects of encapsulated niacin (EN) and parity on caffeine clearance on d 7 postpartum ${ }^{1,2}$

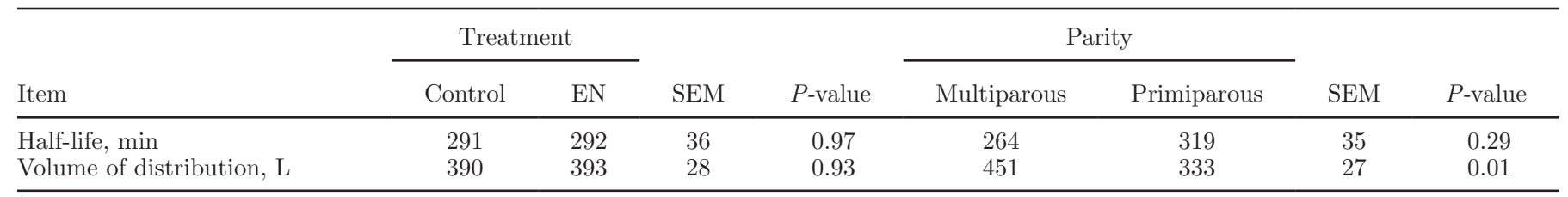

${ }^{1}$ Four missing values (total $\mathrm{n}=18$ ). Treatment $\times$ parity interactions were not significant.

${ }^{2} \mathrm{EN}$ animals received $24 \mathrm{~g} / \mathrm{d}$ of dietary encapsulated niacin.

receptor and is bound in adipose tissue within $5 \mathrm{~min}$ after intravenous injection in mice (Carlson and Hanngren, 1964). Nicotinamide, on the other hand, has a very low affinity for the GPR109A receptor (Gille et al., 2008). Therefore, because plasma NA is short-lived, finding increased plasma concentrations of NA would be unlikely. It may be possible that some of the NAM produced (Huntgate, 1966) and absorbed from the rumen (Erickson et al., 1991) also resulted in increased NAM concentrations, especially for differences between parities and over time. As expected, within $50 \mathrm{~h}$ following the end of treatment, NAM concentrations in treated cows decreased, although they remained slightly higher than in control cows $(P<0.07)$.

In recent work, our group found GPR109A in brain and liver of steers (Bradford et al., 2009b); before this, it was believed that GPR109A was expressed primarily in adipose tissue and immune cells. This novel finding allows us to examine the effects of niacin from a different perspective. Activation of GPR109A receptors in the brain may have resulted in the decreased DMI in treated cows, although it is unknown if the GPR109A receptor influences the satiety center of the brain. Allen et al. (2009) proposed the hepatic oxidation theory as a potential mechanism underlying hypophagia in transition cows caused by increased fatty acid oxidation. The theory proposed that increased hepatic fatty acid oxidation results in hepatic signaling to the brain, causing hypophagia. Therefore, it is possible that the EN-treated multiparous cows had depressed DMI as a result of GPR109A-mediated increases in ATP concentration in the liver, by promoting fatty acid oxidation or by decreasing gluconeogenesis, for example. Regardless, it is difficult to explain why treated primiparous cows did not experience the same depression in DMI as treated multiparous cows. Depression of prepartum

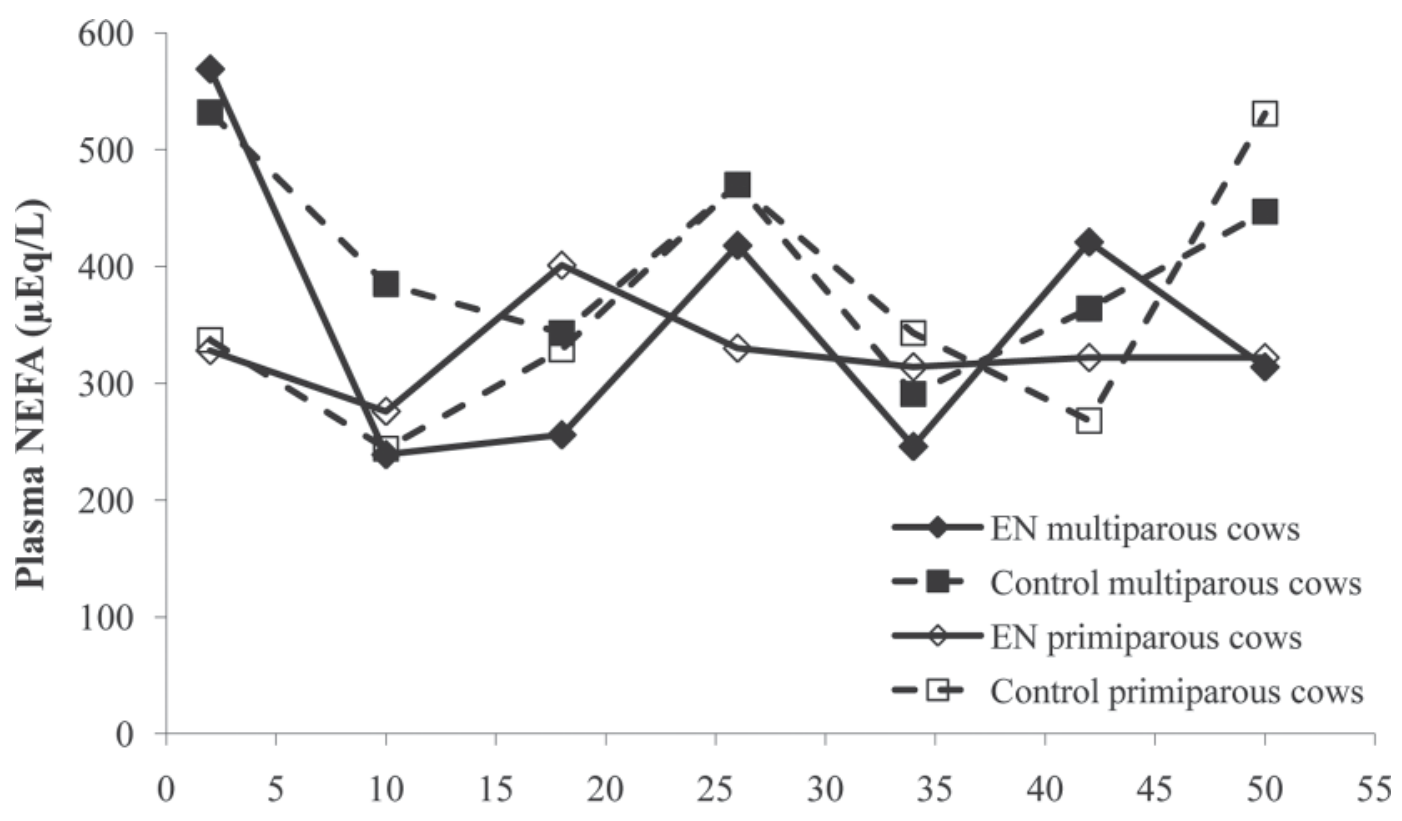

Hours after treatment removal

Figure 6. Plasma concentrations of NEFA during the posttreatment period. A time effect $(P<0.01)$ was observed but no treatment or parity effects. $\mathrm{SEM}=73 \mu \mathrm{Eq} / \mathrm{L}, \mathrm{n}=4$ to 7 . The EN animals received $24 \mathrm{~g} / \mathrm{d}$ of dietary encapsulated niacin for $42 \mathrm{~d}$, with the final treatment provided at time $0 \mathrm{~h}$. 
Table 4. Incidence of diseases during the experimental period ${ }^{1}$

\begin{tabular}{|c|c|c|c|c|}
\hline \multirow[b]{2}{*}{ Disorder } & \multicolumn{2}{|c|}{$\mathrm{EN}^{2}$} & \multicolumn{2}{|c|}{ Control } \\
\hline & $\begin{array}{l}\text { Multiparous } \\
(\mathrm{n}=6)\end{array}$ & $\begin{array}{c}\text { Primiparous } \\
(\mathrm{n}=5)\end{array}$ & $\begin{array}{l}\text { Multiparous } \\
\quad(\mathrm{n}=7)\end{array}$ & $\begin{array}{c}\text { Primiparous } \\
\quad(\mathrm{n}=4)\end{array}$ \\
\hline Ketosis & 3 & 2 & 3 & 2 \\
\hline Metritis & 0 & 1 & 0 & 1 \\
\hline Lameness & 2 & 0 & 2 & 2 \\
\hline Displaced abomasum & 2 & 2 & 1 & 2 \\
\hline Other digestive disorder & 2 & 0 & 1 & 1 \\
\hline At least 1 disorder & 4 & 3 & 6 & 3 \\
\hline At least 2 disorders & 3 & 2 & 3 & 3 \\
\hline
\end{tabular}

${ }^{1}$ No differences existed between treatment or parity groups.

${ }^{2} \mathrm{EN}$ animals received $24 \mathrm{~g} / \mathrm{d}$ of dietary encapsulated niacin.

DMI by EN in multiparous cows is a novel finding and is difficult to explain, but it does raise interesting questions about the role of GPR109A in the liver-brain hunger axis. The apparent decline in DMI of primiparous, EN-treated cows from 15 to 20 DIM was driven by a single cow and was not statistically significant.

Peak plasma NEFA concentrations were lower in EN-treated cows compared with controls. Increased NEFA occurs because of increased lipolysis (Zurek et al., 1995), and the extent of lipolysis depends on the severity of NEB (Drackley et al., 1992; Jorritsma et al.,
2000) and BCS of the animal at parturition (Rukkwamsuk et al., 1998). Because no treatment differences were found in BCS or energy balance during this study, it is likely that niacin directly inhibited lipolysis.

Although EN treatment decreased postpartum plasma NEFA concentration, it did not suppress peak BHBA concentrations in either primiparous or multiparous cows, and it had a significant effect only on plasma BHBA concentrations of primiparous cows on $\mathrm{d} 7$ postpartum. Nonesterified fatty acids are passively taken up by the liver, and uptake is concentration dependent

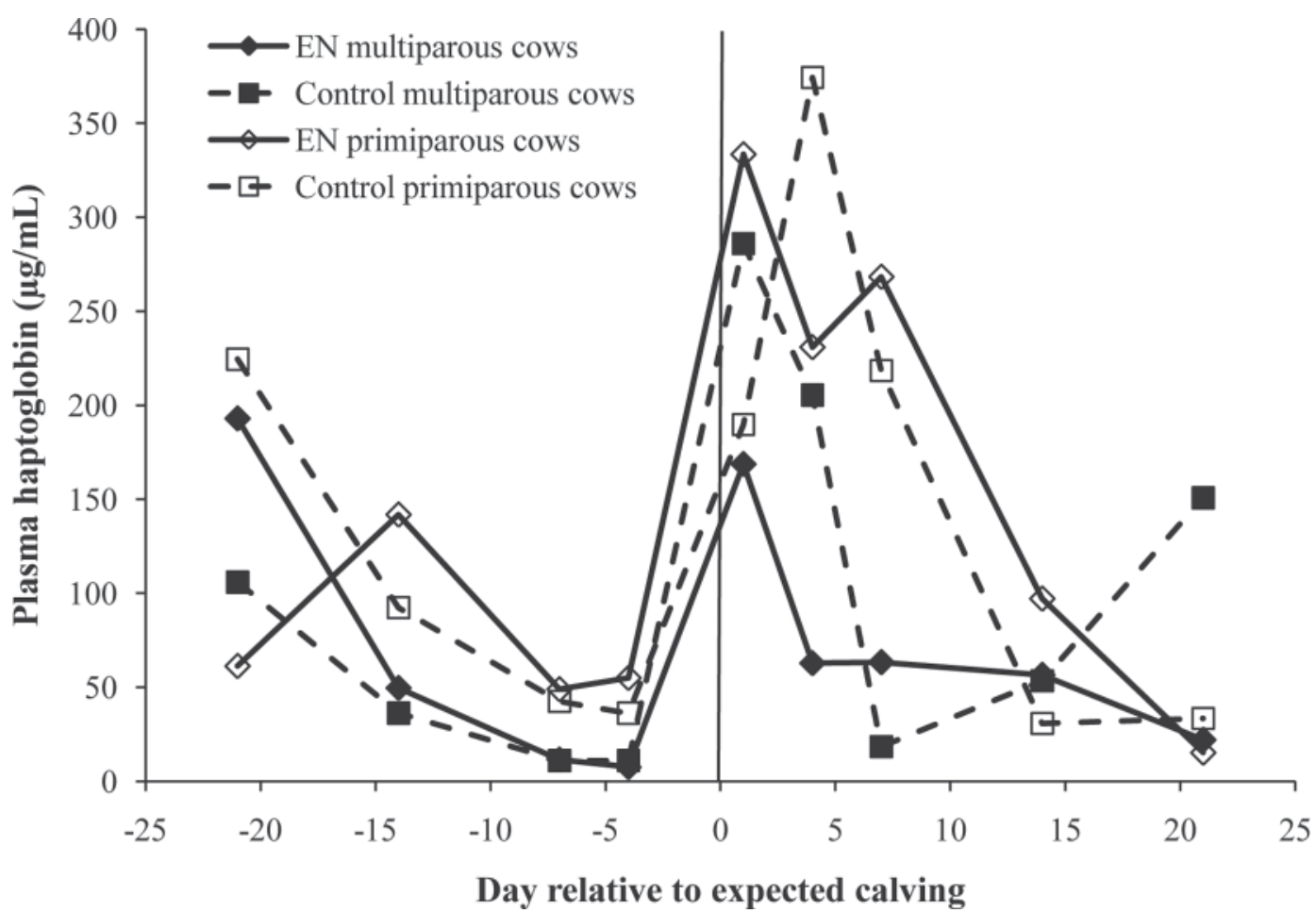

Figure 7. Plasma concentrations of haptoglobin in response to encapsulated niacin (EN) during the periparturient period. A parity effect $(P<0.03)$ was detected, with primiparous cows having higher haptoglobin than multiparous cows $(92.0 \mathrm{vs} .43 .9 \pm 9.6 \mu \mathrm{g} / \mathrm{mL}) . \mathrm{A}$ time effect $(P<0.001)$ and a treatment $\times$ time trend $(P<0.06)$ were also observed. SEM $=62.9 \mu \mathrm{g} / \mathrm{mL}, \mathrm{n}=4$ to 7 . The EN animals received $24 \mathrm{~g} / \mathrm{d}$ of dietary encapsulated niacin. 
(Bell, 1979). Excessive delivery of NEFA to the liver results in TG storage in the cytoplasm and increased mitochondrial production of ketone bodies (Veenhuizen et al., 1991). It is unclear why the significant decrease in NEFA caused by EN did not have more dramatic effects on plasma BHBA concentration, but it is possible that hepatic metabolism of NEFA was also influenced by EN, potentially by shifting a greater proportion of NEFA to the ketogenic pathway; this may explain the tendency for lower hepatic TG on d 1 and 7 in primiparous cows receiving EN.

The fact that plasma NEFA and BHBA concentrations as well as liver TG content were higher in primiparous than in multiparous cows was surprising, given that primiparous cows typically have lower incidence rates of ketosis and fatty liver (Duffield, 2000). However, the fact that the primiparous cows had greater elevations in liver TG may have made them more responsive to treatment effects on plasma NEFA concentration. Elevated plasma NEFA is a primary risk factor for postpartum fatty liver, so we expected that EN would attenuate the accumulation of liver TG in these cows. The small effect of EN on liver TG content in this experiment may be related to the relatively transient effect of treatment on plasma NEFA concentration; for both primiparous and multiparous cows, EN decreased plasma NEFA on only one of the days studied.

The lack of a treatment effect on caffeine clearance rate was inconsistent with our hypothesis that niacin would decrease liver lipid content and therefore improve liver function. The use of caffeine clearance is a relatively novel approach to assessing liver function in lactating dairy cows but has been well validated in other species (Lakritz et al., 2006). Caffeine elimination half-life is highly correlated with liver function (Lakritz et al., 2006) because caffeine is metabolized through the P-450 cytochrome oxidase system (CYP-450; DeGraves et al., 1995). During liver disease, the activity of CYP-450 decreases and the rate of caffeine clearance becomes impaired (McDonagh et al., 1991). It remains unclear whether fatty liver, as typically observed in periparturient dairy cattle, directly impairs the basal functions of the liver, but the caffeine clearance test may provide a tool for answering this question. The literature reports caffeine elimination half-lives in lactating dairy cattle ranging from 156 to $414 \mathrm{~min}$ (DeGraves et al., 1995), which fits very closely with our observed range of 134 to $432 \mathrm{~min}$. Caffeine half-lives were not correlated with concentrations of liver TG or plasma BHBA $(P>0.73)$, but tended to be positively correlated with plasma haptoglobin concentration $(\mathrm{r}=$ 0.43 for log-transformed values; $P=0.07, \mathrm{n}=18$ ). This suggests that liver function may be more closely related to indices of liver inflammation, such as concentrations of acute phase protein, than to traditional measures of metabolic dysfunction, such as liver TG and plasma BHBA concentrations.

The lower prepartum glucose concentration in treated animals without consistent increases in plasma insulin was another unexpected finding. Niacin treatment has been shown to decrease plasma insulin without affecting glucose concentrations (Pires et al., 2007), and increased plasma NEFA is associated with insulin resistance (Pires et al., 2007). It may be possible that the lower prepartum glucose in treated cows was due to increased sensitivity to insulin. However, niacin-mediated increases in insulin sensitivity in the work of Pires et al. (2007) were associated with decreased plasma NEFA concentrations, whereas plasma NEFA was not affected by treatment in the prepartum period in this study. The observed effects on plasma glucose concentration could also be a result of niacin directly stimulating glucose utilization in peripheral tissues or suppressing glucose production by the liver; however, the direct effects of niacin on these tissues are unknown.

The plasma NEFA profile following EN withdrawal (Figure 6) did not suggest that removal of EN led to "rebound lipolysis." The time effect for plasma NEFA following treatment removal was likely due to preprandial increases in lipolysis during the 48-h period (Bradford and Allen, 2008). The feedings occurred at $2,18,26$, and $42 \mathrm{~h}$ following treatment removal, and time points with higher concentrations of NEFA corresponded with expected prefeeding increases in lipolysis. The lack of a rebound effect differs from previous work that demonstrated posttreatment rebounds in plasma NEFA (as high as 4 times the control NEFA concentration) within $6 \mathrm{~h}$ following a single $6 \mathrm{mg} / \mathrm{kg}$ postruminal dose of NA in feed-restricted cows (Pires and Grummer, 2007) and within $3 \mathrm{~h}$ after discontinuing hourly postruminal infusions of NA at a rate equivalent to 56 $\mathrm{g} / \mathrm{d}$ in feed-restricted cows (Pescara et al., 2010). Pescara et al. (2010) also tested lower infusion rates, which did not induce posttreatment rebound lipolysis; however, these doses also failed to suppress plasma NEFA concentrations during the infusion period. Therefore, the treatment protocol used in this study is the first, to our knowledge, to clearly suppress lipolysis in cattle without inducing rebound lipolysis. Several potential explanations exist for the lack of a rebound effect. Administering EN for $42 \mathrm{~d}$ and ending treatment when cows were in positive energy balance may have made cows less prone to the NEFA rebound. However, when women in an energy-neutral state were treated with NA for $1 \mathrm{mo}$, a dramatic rebound lipolysis was documented after treatment ended (Wang et al., 2000), suggesting that, at least in humans, this response is retained with long-term treatment in the absence of NEB. Another 
possibility is that including EN in the diet provided a ruminal reservoir of NA, which prevented an abrupt withdrawal that might correspond to a dramatic change in lipolytic state. In support of this interpretation, use of an extended-release niacin formulation decreased posttreatment rebound lipolysis in humans compared with crystalline niacin treatment, although it was not completely prevented (Vega et al., 2005).

Haptoglobin is an acute phase protein released by the liver during periods of inflammation (Hachenberg et al., 2007) and has been found to be increased in cows with fatty liver (Bobe et al., 2004). Previously it was believed that accumulation of hepatic TG directly caused hepatic damage, but recent literature has indicated that excess NEFA promote lipotoxicity and oxidative stress primarily through other lipid intermediates (including ceramides, diacylglycerols, and lipid peroxides), which may activate inflammatory pathways in the liver (Neuschwander-Tetri, 2010). In our study, primiparous cows had elevated plasma NEFA on d 4 postpartum followed by an increased haptoglobin concentration on d $7(P<0.01)$. The greater haptoglobin in primiparous cows than in multiparous cows indicates that they were suffering from a higher degree of hepatic inflammation, which may have been linked to greater plasma NEFA concentrations and greater flux of FA into the liver. Based on this proposed etiology, we expected that EN treatment would decrease plasma NEFA concentration and subsequently limit hepatic inflammation and plasma haptoglobin concentrations. However, the fact that treatment did not affect plasma haptoglobin concentrations in spite of a significant suppression of plasma NEFA concentration by EN indicates that simply limiting fatty acid flux to the liver during peak lipolysis may be inadequate to limit liver inflammation in periparturient cows. The fact that haptoglobin concentrations are significantly elevated by d 1 postpartum, before peak plasma NEFA concentrations are reached, suggests that other factors may be more critical in eliciting the periparturient liver inflammation. Factors promoting this response may include inflammatory cytokines (Bradford et al., 2009a) or even endocrine factors directly related to parturition. Alternatively, the mild decrease in plasma NEFA concentrations achieved by EN may have been inadequate to suppress a lipotoxic effect in the postpartum liver. These pathways should provide fertile ground for investigation of transition cow metabolism in the coming years.

\section{CONCLUSIONS}

In this study, we found that $24 \mathrm{~g} / \mathrm{d}$ of dietary EN (providing an estimated $9.6 \mathrm{~g} / \mathrm{d}$ of bioavailable NA) inhibited lipolysis in postpartum cows, which was demonstrated by a decrease in postpartum plasma NEFA concentrations. We found that depressed prepartum DMI in EN-treated multiparous cows followed a significantly increased plasma NAM concentration compared with controls. Much remains unknown about GPR109A distribution within the cow and how it affects feed intake. However, we found that even when EN reduced DMI in multiparous cows, it nevertheless suppressed plasma NEFA after calving. Although significant alterations in plasma lipid metabolism were detected after EN treatment, the only difference in liver TG was a tendency $(P=0.10)$ for treated primiparous cows to have less TG than control primiparous cows during the first week of lactation. In contrast to other studies, we found that our NA dose and delivery method did not result in a posttreatment rebound of NEFA. In summary, $24 \mathrm{~g} / \mathrm{d}$ of EN (9.6 g/d of bioavailable NA) can decrease postpartum plasma NEFA, but further research is needed to understand the effects of niacin on prepartum DMI and mechanisms involving postpartum liver metabolism.

\section{ACKNOWLEDGMENTS}

This paper is contribution no. 11-227-J from the Kansas Agricultural Experiment Station. This project was supported in part by USDA-CSREES Section 1433 Animal Health and Disease Funds. The authors express their appreciation to Mike Scheffel, Chad Mullins, and Cynthia Martel for their help with this project, as well as other Kansas State University graduate and veterinary students that helped with sample collection and analysis. We gratefully acknowledge the technical advice of Christiane Girard (Agriculture and Agri-Food Canada, Ottawa, ON, Canada) regarding NA and NAM analyses. We also thank Balchem Corporation (New Hampton, NY), for donation of the Niashure used in this experiment and support for NA and NAM analyses.

\section{REFERENCES}

Allen, M. S., B. J. Bradford, and M. Oba. 2009. Board-invited review: The hepatic oxidation theory of the control of feed intake and its application to ruminants. J. Anim. Sci. 87:3317-3334.

AOAC. 2000. Official Methods of Analysis. 17th ed. Association of Official Analytical Chemists, Arlington, VA.

Bell, A. W. 1979. Lipid metabolism in liver and selected tissues and in the whole body of ruminant animals. Prog. Lipid Res. 18:117-164.

Bobe, G., J. W. Young, and D. C. Beitz. 2004. Invited review: Pathology, etiology and treatments of fatty liver in dairy cows. J. Dairy Sci. $87: 3105-3124$.

Bradford, B. J., and M. S. Allen. 2008. Negative energy balance increases periprandial ghrelin and growth hormone concentrations in lactating dairy cows. Domest. Anim. Endocrinol. 34:196-203.

Bradford, B. J., L. K. Mamedova, J. E. Minton, J. S. Drouillard, and B. J. Johnson. 2009a. Daily injection of tumor necrosis factor- $\alpha$ 
increases hepatic triglycerides and alters transcript abundance of metabolic genes in lactating dairy cattle. J. Nutr. 139:1451-1456.

Bradford, B. J., L. K. Mamedova, K. S. Spivey, and E. C. Titgemeyer. 2009b. Effects of niacin infusion on transcript and protein abundance of the niacin receptor GPR109A in bovine tissues. J. Dairy Sci. 92(E-Suppl. 1):518-519. (Abstr.)

Bradford, M. M. 1976. A rapid and sensitive method for the quantitation of microgram quantities of protein utilizing the principle of protein-dye binding. Anal. Biochem. 72:248-254.

Campbell, J. M., M. R. Murphy, R. A. Christensen, and T. R. Overton. 1994. Kinetics of niacin supplements in lactating dairy cows. J. Dairy Sci. 77:566-575.

Carlson, L. A. 2006. Nicotinic acid and other therapies for raising high-density lipoprotein. Curr. Opin. Cardiol. 21:336-344.

Carlson, L. A., and A. Hanngren. 1964. Initial distribution in mice of ${ }^{3} \mathrm{H}$-labeled nicotinic acid studied with autoradiography. Life Sci. $3: 867-871$

Dann, H. M., N. B. Litherland, J. P. Underwood, M. Bionaz, A D'Angelo, J. W. McFadden, and J. K. Drackley. 2006. Diets during far-off and close-up dry periods affect periparturient metabolism and lactation in multiparous cows. J. Dairy Sci. 89:3563-3577.

DeGraves, F. J., D. C. Ruffin, S. H. Duran, J. S. Spano, E. M. Whatley, J. Schumacher, and M. G. Riddell. 1995. Pharmacokinetics of caffeine in lactating dairy cows. Am. J. Vet. Res. 56:619-622.

Di Costanzo, A., J. N. Spain, and D. E. Spiers. 1997. Supplementation of nicotinic acid for lactating Holstein cows under heat stress conditions. J. Dairy Sci. 80:1200-1206.

Drackley, J. K., T. R. Overton, and G. N. Douglas. 2001. Adaptations of glucose and long-chain fatty acid metabolism in liver of dairy cows during the periparturient period. J. Dairy Sci. 84(E. Suppl.):E100-E112.

Drackley, J. K., M. J. Richard, D. C. Beitz, and J. W. Young. 1992 Metabolic changes in dairy cows with ketonemia in response to restriction and dietary 1, 3-butanediol. J. Dairy Sci. 75:1622-1634.

Duffield, T. F. 2000. Subclinical ketosis in lactating dairy cows. Vet. Clin. North Am. Food Anim. Pract. 16:231-253.

Erickson, P. S., M. R. Murphy, C. S. McSweeney, and A. M. Trusk. 1991. Niacin absorption from the rumen. J. Dairy Sci. 74:34923495.

Fronk, T. J., L. H. Schultz, and A. R. Hardie. 1980. Effect of dry period overconditioning on subsequent metabolic disorders and performance of dairy cows. J. Dairy Sci. 63:1080-1090.

Gille, A., E. T. Bodor, K. Ahmed, and S. Offermanns. 2008. Nicotinic acid: Pharmacological effects and mechanisms of action. Annu. Rev. Pharmacol. Toxicol. 48:79-106.

Grummer, R. R. 1993. Etiology of lipid-related metabolic disorders in periparturient dairy cows. J. Dairy Sci. 76:3882-3896.

Grummer, R. R., D. G. Mashek, and A. Hayirli. 2004. Dry matter intake and energy balance in the transition period. Vet. Clin. North Am. Food Anim. Pract. 20:447-470.

Hachenberg, S., C. Weinkauf, S. Hiss, and H. Sauerwein. 2007. Evaluation of classification modes in potentially suitable to identify metabolic stress in healthy dairy cows during the peripartal period. J. Anim. Sci. 85:1923-1932.

Henderson, L. M. 1983. Niacin. Annu. Rev. Nutr. 3:289-307.

Hungate, R. E. 1966. The Rumen and Its Microbes. Academic Press Inc., New York, NY.

Ingvartsen, K. L., and J. B. Andersen. 2000. Integration of metabolism and intake regulation: A review focusing on periparturient animals. J. Dairy Sci. 83:1573-1597.

Jorritsma, R., H. Jorritsma, Y. H. Schukken, and G. H. Wentink. 2001. Relationships between fatty liver and fertility and some periparturient diseases in commercial Dutch dairy herds. Theriogenology 54:1065-1074

Kelton, D. F., K. D. Lissemore, and R. E. Martin. 1998. Recommendations for recording and calculating the incidence of selected clinical diseases of dairy cattle. J. Dairy Sci. 81:2502-2509.

Lahély, S., M. Bergaentzle, and C. Hasselmann. 1999. Fluorimetric determination of niacin in foods by high-performance liquid chromatography with post-column derivatization. Food Chem. 65:129-133.

Lakritz, J., J. R. Middleton, D. E. Anderson, D. R. Linden, R. A. Sams, R. K. Tessman, and J. W. Tyler. 2006. Pharmacokinetics of intravenously administered caffeine in healthy alpacas (Lama pacos) and llamas (Lama glama). Am. J. Vet. Res. 67:1063-1069.

McDonagh, J. E., V. V. Nathan, I. C. Bonavia, G. R. Moyle, and A. R. Tanner. 1991. Caffeine clearance by enzyme multiplied immunoassay technique: A simple, inexpensive, and useful indicator of liver function. Gut 32:681-684.

NRC. 2001. Nutrient Requirements of Dairy Cattle. 7th rev. ed. Natl. Acad. Sci., Washington, DC.

Neuschwander-Tetri, B. A. 2010. Hepatic lipotoxicity and the pathogenesis of nonalcoholic steatohepatitis: The central role of nontriglyceride fatty acid metabolites. Hepatology 52:774-788.

Pescara, J. B., J. A. A. Pires, and R. R. Grummer. 2010. Antilipolytic and lipolytic effects of administering free or ruminally protected nicotinic acid to feed-restricted Holstein cows. J. Dairy Sci. 93:5385-5396

Pires, J. A. A., and R. R. Grummer. 2007. The use of nicotinic acid to induce sustained low plasma nonesterified fatty acids in feedrestricted Holstein cows. J. Dairy Sci. 90:3725-3732.

Pires, J. A. A., J. B. Pescara, and R. R. Grummer. 2007. Reduction of plasma NEFA concentration by nicotinic acid enhances the response to insulin in feed-restricted Holstein cows. J. Dairy Sci. 90:4635-4642.

Rukkwamsuk, T., T. Wensing, and M. J. H. Geelen. 1998. Effect of overfeeding during the dry period on regulation of adipose tissue metabolism in dairy cows during the periparturient period. J. Dairy Sci. 81:2904-2911.

Santschi, D. E., R. Berthiaume, J. J. Matte, A. F. Mustafa, and C. L. Girard. 2005. Fate of supplementary B-vitamins in the gastrointestinal tract of dairy cows. J. Dairy Sci. 88:2043-2054.

Starke, A., A. Haudum, R. Busche, M. Beyerback, S. Dänicke, and J. Rehage. 2010. Technical note: Analysis of total lipid and triacylglycerol content in small liver biopsy samples in cattle. J. Anim. Sci. 88:2741-2750

Tyrrell, H. F., and J. T. Reid. 1965. Prediction of the energy value of cow's milk. J. Dairy Sci. 48:1215-1223.

Van Soest, P. J., J. B. Robertson, and B. A. Lewis. 1991. Methods for dietary fiber, neutral detergent fiber, non-starch polysaccharides in relation to animal nutrition. J. Dairy Sci. 74:3583-3597.

Veenhuizen, J. J., J. K. Drackley, M. J. Richard, T. P. Sanderson, L. D. Miller, and J. W. Young. 1991. Metabolic changes in blood and liver during development and early treatment of experimental fatty liver and ketosis in cows. J. Dairy Sci. 74:4238-4253.

Vega, G. L., N. B. Cater, S. Meguro, and S. M. Grundy. 2005. Influence of extended-release nicotinic acid on nonesterified fatty acid flux in the metabolic syndrome with atherogenic dyslipidemia. Am. J. Cardiol. 95:1309-1313.

Wang, W., A. Basinger, R. A. Neese, M. Christiansen, and M. K. Hellerstein. 2000. Effects of nicotinic acid on fatty acid kinetics, fuel selection, and pathways of glucose production in women. Am. J. Physiol. Endocrinol. Metab. 279:E50-E59.

Wildman, E. E., G. M. Jones, P. E. Wagner, R. L. Boman, H. F. Troutt, and T. N. Lesch. 1982. A dairy cow body condition scoring system and its relationship to selected production characteristics. J. Dairy Sci. 65:495-501.

Wise, A., S. M. Foord, N. J. Fraser, A. A. Barnes, N. Elshourbagy, M. Eilert, D. M. Ignar, P. R. Murdock, K. Steplewski, A. Green, A J. Brown, S. J. Dowell, P. G. Szekeres, D. G. Hassall, F. H. Marshall, S. Wilson, and N. B. Pike. 2003. Molecular identification of high and low affinity receptors for nicotinic acid. J. Biol. Chem. 278:9869-9874

Zurek, E., G. R. Foxcroft, and J. J. Kennelly. 1995. Metabolic status and interval to first ovulation in postpartum dairy cows. J. Dairy Sci. 78:1909-1920 